\title{
Accelerated Aging Test in Thyme Seeds (Thymus
}

\section{vulgaris L.)}

Flávia Mendes dos Santos Lourenço, Marco Eustáquio de Sá

Universidade Estadual Paulista “Júlio de Mesquita Filho"- UNESP, Departamento de

Fitotecnia e Tecnologia de Alimentos, Ilha Solteira, São Paulo, Brazil

\section{Oscar Mitsuo Yamashita}

Universidade do Estado de Mato Grosso, Programa de Pós-graduação em Biodiversidade e Agroecossistemas Amazônicos, Alta Floresta, Mato Grosso, Brazil

Vinícius Martins Silva, Juliana Trindade Martins, Jéssica Alves de Oliveira, Mayara Favero Cotrim, Renan Furquim da Silva

Universidade Estadual Paulista "Júlio de Mesquita Filho"- UNESP, Departamento de Fitotecnia e Tecnologia de Alimentos, Ilha Solteira, São Paulo, Brazil

\section{Grace Queiroz David, Walmor Moya Peres}

Universidade do Estado de Mato Grosso. Faculdade de Ciências Biológicas e Agrárias, Alta Floresta, Mato Grosso, Brazil

Received: Oct. 9, 2020

doi:10.5296/jas.v9i1.17761
Accepted: Nov. 12, $2020 \quad$ Published: Nov. 16, 2020

URL: https://doi.org/10.5296/jas.v9i1.17761

\begin{abstract}
Evaluating seed quality with precision and accuracy is one of the priorities for obtaining high quality material. This study aimed to evaluate whether the variations in the performance of the accelerated aging test, in terms of exposure time and temperature, in the traditional form or in saline solution, would result in an efficient combination to evaluate the physiological quality of thyme seeds (Thymus vulgaris L.). The seeds were submitted to the tests of total germination, germination speed index, first germination count, seedlings emergence, seedling length, seedling dry mass, cold test, electrical conductivity, variations in the conduction of the accelerated aging test and the water content of the seeds was performed after each accelerated
\end{abstract}


aging period. The treatments were the combination of temperatures $\left(36,38,40\right.$ and $\left.42{ }^{\circ} \mathrm{C}\right)$, exposure time (24, 36, 48 and 72 hours) and two procedures (traditional and saline), with four replications for each batch. Traditional accelerated aging test at $42{ }^{\circ} \mathrm{C}$ and 24 hours of exposure time, and saline solution accelerated aging test at $38{ }^{\circ} \mathrm{C}$ and 24 hours of exposure time showed sensibility to evaluate physiological potential for thyme seed. For both saline solution and traditional accelerated aging test, the exposition time of 24 hours was efficient to evaluate physiological potential of thyme seeds.

Keywords: exposure time, temperature, vigor, adaptation methodology, physiological quality of seeds, germination

\section{Introduction}

The thyme (Thymus vulgaris L.) is a Lamiaceae plant, native from Western Mediterranean region of Europe, is profusely found throughout southern France, Portugal, Spain and Italy (Digest, 1999). Thyme has insecticidal, fungicidal, antioxidant and phenolic properties. It could be used as a food condiment, as a spice (Miranda et al., 2015).

The secondary metabolites of these plants, mainly the essential oils, have been studied mostly to develop alternative methods to control crop pests, diseases and weeds (Saito, 2004). On the other hand, there is a lack of studies regarding physiological properties of thyme seeds, presenting few informations on their physiological quality.

Seed companies must take decisions quickly referring to harvest management, reception, processing, storage and commercialization. Considering that, reducing the time to evaluate physiological seed quality is a priority. In that sense, vigor tests has been considered a tool increasingly used by seed companies to determinate the physiological potential of seeds (Silva et al., 2010).

One of these tests is the accelerated aging test, which is based in the increasing of seeds deterioration rate, by exposition to high levels of temperature and air humidity, being these the environmental factors that most influence the intensity and speed of seeds deterioration (Marcos Filho, 1999a). Alternatives to perform accelerated aging test were studied, for example, the replacement of water content placed in the plastic box by saturated salt solution. This initiative affords relative humidity around $76 \%$ using $\mathrm{NaCl}$, reducing the water uptake and deterioration speed, providing less drastic effects under seeds, generating fewer variable results (Jianhua and McDonald, 1996; Panobianco and Marcos Filho, 2001).

This study aimed to evaluate the variations in accelerated aging test, in terms of time and temperature exposure involved in test methodology, realized in traditional form or in saline solution, to determine in an efficient combination to evaluate physiological seed quality of thyme (Thymus vulgaris L.).

\section{Material and Methods}

The experiment was conducted at the seed analysis laboratory of the São Paulo State University "Júlio de Mesquita Filho" - UNESP - Campus Ilha Solteira - SP. There was used three commercial batches of thyme seeds untreated. The seeds were submitted to tests of total 
germination, germination speed index, first germination count, seedling emergence, seedling length, seedling dry mass, cold test, electrical conductivity and variations in the conduction of the accelerated aging test.

The water content determination was performed by oven method at $105 \pm 2{ }^{\circ} \mathrm{C}$, during 24 hours (Brasil, 2009), being realized two subsamples of 20 seeds for each batch. The germination test was performed with four replicates composed by 50 seeds each, distributed in plastic boxes (gerbox) containing a germibox sheet moistened with deionized water, the water content in the germibox was in the proportion of 2.5:1 considering the dry germibox sheet mass. The box where keeps in germinator at $25^{\circ} \mathrm{C}$, the counting score was performed at 21 days after sowing (Brasil, 2009). The first counting score was realized in conjunction with the germination test, computing normal seedlings obtained at seven days after the test installation.

The speed germination index was performed in conjunction with the germination test, the calculations ware realized according to Maguire (1962), in which daily counting were executed from the germination test installation as established by RSA (Rules for Seeds Analysis), in which, the number of normal seedlings was computed.

To seedlings emergence test execution, there was used expanded polystyrene boxes containing substrate and under daily irrigation (twice a day). The seedling evaluation was performed at 21 days after sowing, by considering emerged seedlings the ones with both cotyledon leaves open and above the substrate. (Nakagawa, 1999). The evaluation was performed using four replications with 50 seeds in each. After counting, ten seedlings of each replication were separated in shoots and roots, the material was accommodated in a forced circulation thermoelectric oven at $65{ }^{\circ} \mathrm{C}$ for 48 hours. The dried samples were weighted in an analytical scale $(0.0001 \mathrm{~g})$, the total weight obtained in each replication was divided by the total number of seedlings evaluated in each replication, resulting in the seedling mean dry mass.

To seedling growth, four replications with 20 seeds per treatment were used. The seeds were sown using three sheets of germitest paper, being two sheets under the seeds and one above, the seeds were placed in the space marked by a line drawn in the upper third with a distance of $3 \mathrm{~cm}$ in the longitudinal direction. The samples in paper rolls were placed inside plastic bags and closed with rubber band. The material was allocated in germinator and remaining for seven days in the dark at $25^{\circ} \mathrm{C}$. After this period, the normal shoot and seed length was measure, in centimeters $(\mathrm{cm})$, using a graduated rule with $\mathrm{mm}$ precision (Nakagawa, 1999).

In conjunction with the seedlings length test, the seedlings dry mass test was performed in which the measured seedlings were placed in paper bags and carried to thermoelectric dry oven with forced air circulation, at $65{ }^{\circ} \mathrm{C}$ by 48 hours. After drying, the samples were weighted using analytical scale $(0.0001 \mathrm{~g})$, the weight observed for each replication was divided by the number of normal seedlings evaluated, resulting in the average dry mass per seedling.

For cold test, four replications with 50 seeds each were used in each batch, distributed in 
plastic boxes (gerbox), containing a germibox paper sheet moistened with deionized water in proportion of 2.5 times the dry germibox paper mass. The boxes were kept in B.O.D. at $10^{\circ} \mathrm{C}$ by seven days. Then, were transferred to germinator at constant temperature of $25^{\circ} \mathrm{C}$, were remained for more seven days, when the number of normal seedlings was computed.

In the conductivity electrical test, 25 seeds were weighted using analytical scale $(0.0001 \mathrm{~g})$, being placed in plastic cups containing $75 \mathrm{~mL}$ of deionized water. The material was kept in germinator during 24 hours at $25^{\circ} \mathrm{C}$. The electrical conductivity measurements were realized in conductivity meter and the mean values express in $\mu \mathrm{S} . \mathrm{cm}^{-1} \cdot \mathrm{g}^{-1}$ of seed.

The accelerated aging test (traditional procedure) was carried out using transparent plastic boxes $(11.5 \times 11.5 \times 3.5 \mathrm{~cm})$ with individual compartments (mini-chambers), known as gerbox method. The boxes had in its interior, supports for metallic screen. On the surface of each of these, were distributed in a single layer, approximately 220 seeds for each batch. To control the relative humidity within the boxes, $40 \mathrm{~mL}$ of deionized water were placed in each box. The boxes were capped and kept in B.O.D during the different aging tests periods of 24 , 36,48 and 72 hours, at $36,38,40$ and $42{ }^{\circ} \mathrm{C}$.

After each aging period, the seeds were submitted at total germination test, with the evaluation being realized seven days after sowing. The results were expressed in percentage by normal seedlings, for each batch. After each aging period, the seed humidity index was also determined, aiming to evaluate the uniformity of the test imposed by the test conditions.

The aging test using $\mathrm{NaCl}$ solution was carried out in the same manner as the traditional, except that $40 \mathrm{~mL}$ of saturated $\mathrm{NaCl}$ solution was added to the bottom of the plastic box, replacing the deionized water. The $\mathrm{NaCl}$ solution was made by adding $40 \mathrm{~g}$ of $\mathrm{NaCl}$ in 100 $\mathrm{mL}$ of deionized water, thereby establishing an environment with $76 \%$ relative humidity (Jianhua and McDonald, 1996).

The experiment was carried out in a completely randomized design with treatments obtained from the combination of temperatures (4), exposition times (4) and procedures (2), with four replications in each batch. The means were compared by Tukey test at 5\%. The simple correlation coefficient ( $r$ ) between the results of the accelerated aging tests (traditional and saline procedure) and the seedling emergence test of seedlings in substrate were also determined. When necessary, the data transformation was performed: by $\log _{10} \mathrm{Y}$ for electrical conductivity, and by $\sqrt{ } \mathrm{Y}=0,5$ for seedling length and dry mass.

\section{Results and Discussion}

The seeds presented low water content (Table 1), which is a characteristic of vegetable and ornamental seeds, especially when in hermetic packages. According to Tunes et al. (2011), when seeds presented lower water content, it is possible to obtain better reliability in the results obtained in the physiological quality tests. 
Table 1. Humidity level (HL), germination (G), first counting score (FCS), germination speed index (GSI), electrical conductivity (EC), seedlings emergence (SE), cold test (CT), shoot length (SL), root length (RL), shoot dry weight (SDW), root dry weight (RDT), emergence shoot dry weight (ESDW) and emergence root dry weight (ERDW), in three batches of thyme (Thymus vulgaris L.)

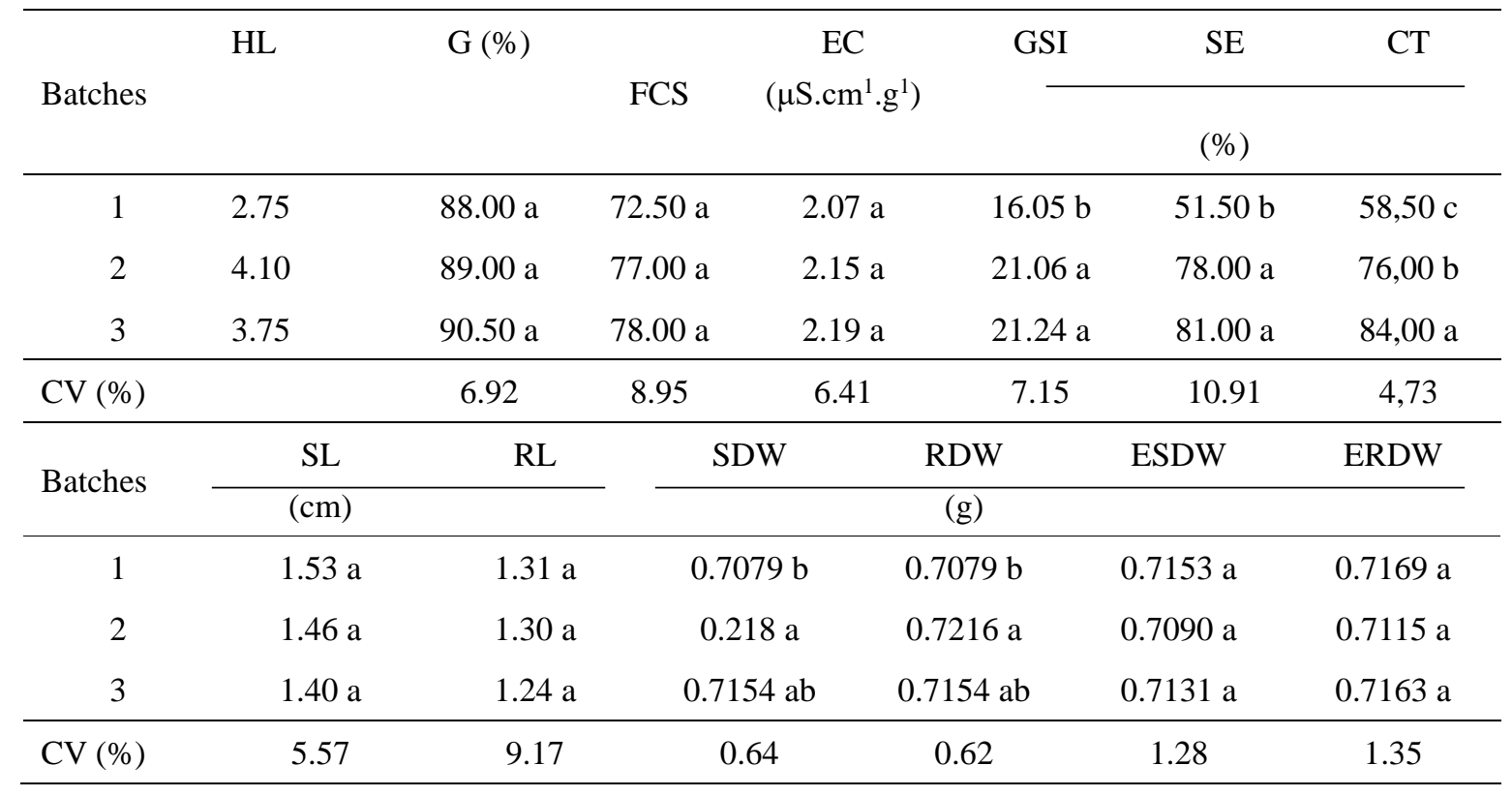

Different letters within each column differ according to Tukey test at 5\% probability.

The total germination test and the first germination count did not present statistical difference among the three thyme seed batches (Table 1). Thus, the total germination test performed under optimum conditions of water, temperature and oxygen, might often not detect possible differences in vigor between batches.

The first counting score might be considered a vigor indicator, although the decrease in seeds germination speed is not one of the first events in the deterioration seed process (Delouche and Baskin, 1973), justifying the lower efficiency of the first counting score in the thyme seeds, in detecting few differences in vigor (Table 1).

The electrical conductivity test did not present statistical difference for the batches (Table 1), however, in the literature there are several reports of this type of behaviour. Albuquerque et al. (2001) using four sunflower genotypes evaluated seed quality by electrical conductivity, they found that the test was not very efficient in evaluating of the genotypes. According to Marcos Filho (2015), one of the indicatives of the vigor reduction is the decrease in the number of normal seedlings, with greater requirement of the plants in relation to the conditions of the environment. The low physiological potential in the batches might be observed by the larger interval between sowing and germination. Thereby, the germination speed index in comparison with the first counting score showed that the batches that presented low performance in the first counting score, also showed low germination speed index. (Table 1). The germination speed index performed statistical difference in the batches, exposing inferiority in the batch 1 compared to the other two (Table 1). 
The seedling emergence test is an efficiency parameter indicator for the other tests that evaluate the physiological potential of seed batches (Marcos Filho, 2005). Thus, the seedlings emergence test, in substrate, was sensitive in present the physiological potential in the different thyme batches, showing the low physiological potential in the batch 1 in comparison with the others (Table 1), thus, presenting agreement with germination speed index (Table 1).

Considering the cold test, the batch 3 showed a better performance compared to batches 1 and 2 (Table 1). According to Marcos Filho (2015), the vigor loss is characterized initially by small changes in germination speed, higher emergence time and higher sensibility to adverse environmental conditions. This could be observed in the cold test results, in which, there is an indicative of significant reduction in the physiological quality of the seeds, in conditions of low temperature and high humidity.

The shoot length and dry weight, primary root length and dry weight of thyme seed of emergence in substrate did not present significantly difference among the three batches (Table 1). However, the shoot dry weight and root dry weight in germination, presented were higher in batch 2 compared to batch 1, reinforcing the results by the tests of starting vigor (emergence speed index, seedling emergence and cold test; Table 1), in which the batch 1 presented lower performance compared with the others. Thus, it is expected that batch 1 presented a lower physiological potential when submitted to accelerated aging test or exposed to adverse environmental conditions.

In the traditional procedure, was observed that batch 1 presented the lower physiological potential in every aging periods and temperatures used (Table 2), forcing the initial evaluations (emergence speed index, seedling emergence and cold test; Table 1), except in 72 hours at 38 and $42{ }^{\circ} \mathrm{C}$. In pepper seeds, the aging test at 38 or $42{ }^{\circ} \mathrm{C}$. Was effective to classify batches in different vigor levels (Bhering et al., 2006).

For 36,38 and $42{ }^{\circ} \mathrm{C}$, the exposition time of 24 hours was the one that better separated the three batches according to vigor, in which, batch 3 presented higher quality than the other two batches (Table 2). For $40{ }^{\circ} \mathrm{C}$, the 24 hours period was not the best fitted to evaluate batches quality, being the periods of 48 and 78 hour the more fitted to $40{ }^{\circ} \mathrm{C}$ (Table 2); thus, presenting agreement in the ordering of the batches regarding the initial evaluations (emergence speed index, seedling emergence and cold test; Table 1). The one of theirs studies Ohlson et al. (2010), found that the period of 48 hours allowed to differentiate batches of wheat seeds. However, Torres and Marcos Filho (2001) found that the period of 48 hours at $41{ }^{\circ} \mathrm{C}$ is not very sensitive to estimate the physiological potential of cackrey seeds (Cucumis anguria $\mathrm{L}$.), indicating that the ideal time varies among species.

Regarding to conditioning time, it was observed that 24 hours of accelerated aging was effective to separate the batches in different vigor levels, reinforcing the better performance observed in batch 3 (Table 2). Although a lot of studies have been carried out, there are no consensus among the researchers regarding the best period for accelerated aging test for seeds of several species of economic importance (Alves and Sá, 2012). 
Table 2. Normal seedlings percentage (\%) of thyme (Thymus vulgaris L.), after traditional aging periods

\begin{tabular}{|c|c|c|c|c|c|c|c|c|}
\hline \multirow{4}{*}{ Batches } & \multicolumn{8}{|c|}{ Traditional accelerated aging test } \\
\hline & \multicolumn{4}{|c|}{$36^{\circ} \mathrm{C}$} & \multicolumn{4}{|c|}{$38^{\circ} \mathrm{C}$} \\
\hline & 24 & 36 & 48 & 72 & 24 & 36 & 48 & 72 \\
\hline & \multicolumn{4}{|c|}{$(\%)$} & \multicolumn{4}{|c|}{$(\%)$} \\
\hline 1 & $35.0 \mathrm{c}$ & $39.0 \mathrm{~b}$ & $52.5 \mathrm{~b}$ & $54.0 \mathrm{~b}$ & $40.5 \mathrm{~b}$ & $48.5 \mathrm{~b}$ & $55.0 \mathrm{c}$ & $49.0 \mathrm{a}$ \\
\hline 2 & $56.0 \mathrm{~b}$ & $65.5 \mathrm{a}$ & $62.5 \mathrm{a}$ & $57.5 \mathrm{ab}$ & $59.5 \mathrm{a}$ & $64.5 \mathrm{a}$ & $70.8 \mathrm{a}$ & $50.0 \mathrm{a}$ \\
\hline 3 & $74.5 \mathrm{a}$ & $41.5 \mathrm{~b}$ & $62.5 \mathrm{a}$ & $59.5 \mathrm{a}$ & $60.0 \mathrm{a}$ & $65.5 \mathrm{a}$ & $59.5 \mathrm{~b}$ & $47.0 \mathrm{a}$ \\
\hline \multicolumn{9}{|c|}{ CV $(\%) 4.51$} \\
\hline & \multicolumn{4}{|c|}{$40^{\circ} \mathrm{C}$} & \multicolumn{4}{|c|}{$42{ }^{\circ} \mathrm{C}$} \\
\hline & 24 & 36 & 48 & 72 & 24 & 36 & 48 & 72 \\
\hline & \multicolumn{4}{|c|}{$(\%)$} & \multicolumn{4}{|c|}{$(\%)$} \\
\hline 1 & $50.5 \mathrm{~b}$ & $62.5 \mathrm{c}$ & $43.5 \mathrm{c}$ & $29.0 \mathrm{~b}$ & $34.0 \mathrm{c}$ & $23.5 \mathrm{c}$ & $45.5 \mathrm{c}$ & $48.0 \mathrm{a}$ \\
\hline 2 & $75.0 \mathrm{a}$ & $73.5 \mathrm{~b}$ & $64.7 \mathrm{~b}$ & $67.5 \mathrm{a}$ & $48.0 \mathrm{~b}$ & $58.5 \mathrm{~b}$ & $59.0 \mathrm{~b}$ & $33.0 \mathrm{~b}$ \\
\hline 3 & $74.0 \mathrm{a}$ & $80.0 \mathrm{a}$ & $75.5 \mathrm{a}$ & $63.5 \mathrm{a}$ & $54.0 \mathrm{a}$ & $70.0 \mathrm{a}$ & $72.0 \mathrm{a}$ & $46.5 \mathrm{a}$ \\
\hline $\mathrm{CV}(\%)$ & & & & & & & & \\
\hline
\end{tabular}

Different letters within each column differ according to Tukey test at 5\% probability.

Some studies with vegetable seeds stand out in the literature, through various exposure periods, for instance: Eruca sativa at $41^{\circ} \mathrm{C} / 48 \mathrm{~h}$ (Ramos et al., 2004) and at $41^{\circ} \mathrm{C} / 72$ and 96 h (Alves and Sá, 2012) and Cucumis anguria at $41^{\circ} \mathrm{C} / 72 \mathrm{~h}$ (Torres and Marcos Filho, 2001).

In the saline solution procedure, the batch 1 presented the worst performance (Table 3), reinforcing the initial tests (Table 1) and the accelerated aging test in traditional procedure (Table 2). For temperatures of 36 and $38^{\circ} \mathrm{C}$, the $24 \mathrm{~h}$ period stand out in batches differentiation. However, for $40{ }^{\circ} \mathrm{C}$, the $72 \mathrm{~h}$ period was the one to stand out in batches differentiation, and for $42^{\circ} \mathrm{C}$, the better-fitted period was $48 \mathrm{~h}$ (Table 3).

Studies of Freitas and Nascimento (2006), found that the use of saline solution in lentil seeds, in the period of 48 hours at $41^{\circ} \mathrm{C}$, was the most appropriate procedure for the classification of batches at different levels of vigor. For Torres (2005), the period of $72 \mathrm{~h}$ at 38 and $41{ }^{\circ} \mathrm{C}$ using saline solution, was the most fitted for evaluation of chilli pepper seeds. For Godoy et al. (2012), the accelerated aging test in saline solution at $42^{\circ} \mathrm{C}$ for $24 \mathrm{~h}$, presented sensitivity to evaluate the physiological potential of carrot seeds.

The accelerated aging test in saline solution is promising to use in quality controls programs, since in addition to providing conditions for absorption of smaller and more uniform amounts of water by the seeds, it requires equipment and methodology similar to the conventional method (without $\mathrm{NaCl}$ ) (Torres, 2005).

However, there are some difficulties in the execution of accelerated test with saline solution 
(Table 3), this test may increase the amount of salt in thyme seeds to very high amounts, making achievement difficult. The transparent plastic box (gerbox), the traditional material used to realize the accelerated aging test, have a depth relatively shallow considering the bottom distance to the metallic mesh and the thyme seeds diameter, which were on the surface, facilitating the saturated water and seed contact. Due to the small size of the seed, this water contact elevated the salt content and impaired the seeds germination after the accelerated aging period. Justifying the decrease in the germination of thyme seeds exposed to saline solution procedure in accelerated aging test (Table 3).

Table 3. Normal seedlings percentage (\%) of thyme (Thymus vulgaris L.), after saline solution aging periods

\begin{tabular}{|c|c|c|c|c|c|c|c|c|}
\hline \multirow{4}{*}{ Batches } & \multicolumn{8}{|c|}{ Saline solution accelerated aging test } \\
\hline & \multicolumn{4}{|c|}{$36^{\circ} \mathrm{C}$} & \multicolumn{4}{|c|}{$38^{\circ} \mathrm{C}$} \\
\hline & $24 \mathrm{~h}$ & $36 \mathrm{~h}$ & $48 \mathrm{~h}$ & $72 \mathrm{~h}$ & $24 \mathrm{~h}$ & $36 \mathrm{~h}$ & $48 \mathrm{~h}$ & $72 \mathrm{~h}$ \\
\hline & \multicolumn{4}{|c|}{$(\%)$} & \multicolumn{4}{|c|}{$(\%)$} \\
\hline 1 & $26.0 \mathrm{~b}$ & $65.5 \mathrm{a}$ & $42.5 \mathrm{a}$ & $40.0 \mathrm{a}$ & $33.5 \mathrm{~b}$ & $64.5 \mathrm{a}$ & $57.5 \mathrm{~b}$ & $49.5 \mathrm{a}$ \\
\hline 2 & $55.5 \mathrm{a}$ & $68.0 \mathrm{a}$ & $44.5 \mathrm{a}$ & $43.0 \mathrm{a}$ & $83.0 \mathrm{a}$ & $75.5 \mathrm{a}$ & $80.8 \mathrm{a}$ & $61.0 \mathrm{a}$ \\
\hline 3 & $69.0 \mathrm{a}$ & $24.0 \mathrm{~b}$ & $45.0 \mathrm{a}$ & $40.0 \mathrm{a}$ & $79.5 \mathrm{a}$ & $69.5 \mathrm{a}$ & $12.0 \mathrm{c}$ & $55.2 \mathrm{a}$ \\
\hline $\mathrm{CV}(\%)$ & & 1.71 & & & & & & \\
\hline \multirow{3}{*}{ Batches } & \multicolumn{4}{|c|}{$40^{\circ} \mathrm{C}$} & \multicolumn{4}{|c|}{$42^{\circ} \mathrm{C}$} \\
\hline & $24 \mathrm{~h}$ & $36 \mathrm{~h}$ & $48 \mathrm{~h}$ & $72 \mathrm{~h}$ & $24 \mathrm{~h}$ & $36 \mathrm{~h}$ & $48 \mathrm{~h}$ & $72 \mathrm{~h}$ \\
\hline & \multicolumn{4}{|c|}{$(\%)$} & \multicolumn{4}{|c|}{$(\%)$} \\
\hline 1 & $69.0 \mathrm{a}$ & $63.5 \mathrm{a}$ & $63.5 \mathrm{a}$ & $50.0 \mathrm{~b}$ & $59.0 \mathrm{~b}$ & $64.0 \mathrm{a}$ & $34.5 \mathrm{~b}$ & $53.0 \mathrm{a}$ \\
\hline 2 & $77.0 \mathrm{a}$ & $78.0 \mathrm{a}$ & $81.3 \mathrm{a}$ & $70.5 \mathrm{a}$ & $79.0 \mathrm{a}$ & $80.0 \mathrm{a}$ & $77.0 \mathrm{a}$ & $59.0 \mathrm{a}$ \\
\hline 3 & $71.5 \mathrm{a}$ & $75.5 \mathrm{a}$ & $76.5 \mathrm{a}$ & $74.0 \mathrm{a}$ & $64.5 \mathrm{ab}$ & $67.5 \mathrm{a}$ & $60.0 \mathrm{a}$ & $65.0 \mathrm{a}$ \\
\hline $\mathrm{CV}(\%)$ & & 1.71 & & & & & & \\
\hline
\end{tabular}

Different letters within each column differ according to Tukey test at 5\% probability.

The seeds showed low humidity, in the beginning, for test achievements (Table 1), however high humidity in the end of the tests (Table 4), this fact reinforces Ramos et al. (2004) affirmations, that in small seeds, great water absorptions variation may occur, providing inconsistent results. Likewise, additional care should be taken when using B.O.D. type cameras, in accelerated aging test realization, these cares are necessary to avoid temperature fluctuations, and so, to provide more reliable results. According to Tekrony (2003), temperature variations of $0.5{ }^{\circ} \mathrm{C}$ in accelerated aging chambers may significantly affect the test results, changing sampling performance, and usually, benefiting those with average vigor. Thus, a strict control in temperature is fundamental to provide reliable results of seed behavior.

In tables 4 and 5, the data regarding water content after accelerated aging test are presented. It was observed that, for the accelerated aging test in saline solution, the seed batches stablished for each treatment presented relative humidity inferior compared to seeds exposed to traditional procedure for accelerated aging test, showing the efficiency of the test with saline solution in decrease the humidity inside the plastic box, thus, decreasing the speed and intensity of seeds deterioration. In studies, Tunes et al. (2012) observed that broccoli seeds aged traditionally, hit higher water content and with higher variation in comparison to 
broccoli seeds aged in saline solution.

Table 4. Water content (\%) of three bathes of thyme (Thymus vulgaris L.), after traditional aging period

\begin{tabular}{|c|c|c|c|c|c|c|c|c|}
\hline \multirow{4}{*}{ Batches } & \multicolumn{8}{|c|}{ Traditional accelerated aging } \\
\hline & \multicolumn{4}{|c|}{$36^{\circ} \mathrm{C}$} & \multicolumn{4}{|c|}{$38^{\circ} \mathrm{C}$} \\
\hline & $24 \mathrm{~h}$ & $36 \mathrm{~h}$ & $48 \mathrm{~h}$ & $72 \mathrm{~h}$ & $24 \mathrm{~h}$ & $36 \mathrm{~h}$ & $48 \mathrm{~h}$ & $72 \mathrm{~h}$ \\
\hline & \multicolumn{4}{|c|}{$(\%)$} & \multicolumn{4}{|c|}{$(\%)$} \\
\hline 1 & 27.14 & 27.16 & 3.78 & 40.65 & 24.00 & 30.14 & 37.17 & 38.54 \\
\hline 2 & 25.70 & 28.34 & 35.91 & 39.21 & 23.33 & 33.81 & 36.84 & 37.17 \\
\hline \multirow[t]{2}{*}{3} & 28.57 & 27.75 & 39.64 & 37.76 & 24.61 & 31.98 & 36.52 & 39.90 \\
\hline & \multicolumn{4}{|c|}{$40^{\circ} \mathrm{C}$} & \multicolumn{4}{|c|}{$42{ }^{\circ} \mathrm{C}$} \\
\hline \multirow[t]{2}{*}{ Batches } & $24 \mathrm{~h}$ & $36 \mathrm{~h}$ & $48 \mathrm{~h}$ & $72 \mathrm{~h}$ & $24 \mathrm{~h}$ & $36 \mathrm{~h}$ & $48 \mathrm{~h}$ & $72 \mathrm{~h}$ \\
\hline & \multicolumn{4}{|c|}{$(\%)$} & \multicolumn{4}{|c|}{$(\%)$} \\
\hline 1 & 26.60 & 30.76 & 34.92 & 42.06 & 29.15 & 30.94 & 32.73 & 42.84 \\
\hline 2 & 28.04 & 34.91 & 37.46 & 42.44 & 22.04 & 33.83 & 34.95 & 42.56 \\
\hline 3 & 29.48 & 32.83 & 36.19 & 41.67 & 25.60 & 36.71 & 37.16 & 42.70 \\
\hline
\end{tabular}

Table 5. Water content (\%) of three bathes of thyme (Thymus vulgaris L.), after traditional aging period

\begin{tabular}{|c|c|c|c|c|c|c|c|c|}
\hline \multirow{4}{*}{ Batches } & \multicolumn{8}{|c|}{ Saline solution accelerated aging test } \\
\hline & \multicolumn{4}{|c|}{$36^{\circ} \mathrm{C}$} & \multicolumn{4}{|c|}{$38^{\circ} \mathrm{C}$} \\
\hline & $24 \mathrm{~h}$ & $36 \mathrm{~h}$ & $48 \mathrm{~h}$ & $72 \mathrm{~h}$ & $24 \mathrm{~h}$ & $36 \mathrm{~h}$ & $48 \mathrm{~h}$ & $72 \mathrm{~h}$ \\
\hline & \multicolumn{4}{|c|}{$(\%)$} & \multicolumn{4}{|c|}{$(\%)$} \\
\hline 1 & 12.25 & 16.34 & 18.25 & 20.06 & 15.34 & 17.45 & 19.22 & 23.20 \\
\hline 2 & 11.12 & 17.95 & 18.74 & 19.26 & 16.88 & 17.79 & 19.24 & 22.32 \\
\hline \multirow[t]{2}{*}{3} & 13.37 & 17.75 & 19.55 & 23.45 & 16.11 & 18.13 & 19.26 & 24.07 \\
\hline & \multicolumn{4}{|c|}{$40^{\circ} \mathrm{C}$} & \multicolumn{4}{|c|}{$42{ }^{\circ} \mathrm{C}$} \\
\hline \multirow[t]{2}{*}{ Batches } & $24 \mathrm{~h}$ & $36 \mathrm{~h}$ & $48 \mathrm{~h}$ & $72 \mathrm{~h}$ & $24 \mathrm{~h}$ & $36 \mathrm{~h}$ & $48 \mathrm{~h}$ & $72 \mathrm{~h}$ \\
\hline & \multicolumn{4}{|c|}{$(\%)$} & \multicolumn{4}{|c|}{$(\%)$} \\
\hline 1 & 11.60 & 13.97 & 16.47 & 22.53 & 17.44 & 17.93 & 18.42 & 26.91 \\
\hline 2 & 13.22 & 14.38 & 15.77 & 23.61 & 16.16 & 16.27 & 17.45 & 26.03 \\
\hline 3 & 14.83 & 14.95 & 15.07 & 24.69 & 16.80 & 17.10 & 17.94 & 27.78 \\
\hline
\end{tabular}

It was observed that, to traditional accelerated aging test, there was a significate correlation of seedlings emergence in substrate to: 24 hours at 36,38 and $42{ }^{\circ} \mathrm{C} ; 36$ hours at $42{ }^{\circ} \mathrm{C} ; 48$ and 72 hours at $40{ }^{\circ} \mathrm{C}$ (Table 6). To accelerated aging test in saline solution, there was a significate correlation of seedlings emergence in substrate to 24 hours ate 36 and $38^{\circ} \mathrm{C}$ (Table 6). Thus, these combinations are related to seedlings emergence, and may be considered 
efficient to identify vigor differences in thyme seed batches regarding the physiological potential. The positive correlation with emergence is very important, showing that, aged thyme seeds in periods of $24,36,48$ and 72 hours at $36,38,40$ and $42{ }^{\circ} \mathrm{C}$ could present high performance in field conditions.

Table 6. Simple correlation coefficient (r) among data obtained according to accelerated aging test (traditional and saline solution procedure) and seedling emergence for three thyme bathes (Thymus vulgaris L.)

\begin{tabular}{|c|c|c|c|c|c|c|c|c|}
\hline \multirow{2}{*}{ Temp. } & \multicolumn{4}{|c|}{ Traditional solution } & \multicolumn{4}{|c|}{ Saline solution } \\
\hline & $24 \mathrm{~h}$ & $36 \mathrm{~h}$ & $48 \mathrm{~h}$ & $72 \mathrm{~h}$ & $24 \mathrm{~h}$ & $36 \mathrm{~h}$ & $48 \mathrm{~h}$ & $72 \mathrm{~h}$ \\
\hline $36^{\circ} \mathrm{C}$ & $0.83^{*}$ & 0.44 & 0.49 & 0.24 & $0.83^{*}$ & -0.41 & 0.31 & 0.35 \\
\hline $38^{\circ} \mathrm{C}$ & $0.92^{*}$ & 0.63 & 0.39 & -0.14 & $0.84^{*}$ & 0.50 & -0.26 & -0.37 \\
\hline $40^{\circ} \mathrm{C}$ & 0.78 & 0.65 & $0.85^{*}$ & $0.82^{*}$ & 0.24 & 0.72 & 0.71 & 0.78 \\
\hline $42^{\circ} \mathrm{C}$ & $0.93^{*}$ & $0.90^{*}$ & 0.55 & -0.37 & 0.46 & 0.33 & 0.67 & -0.23 \\
\hline
\end{tabular}

* $\mathrm{r}$ significant at $5 \%$ de probability $(0,8 \leq \mathrm{R}<1)$.

\section{Conclusions}

The traditional accelerated aging test using the combination of 24 hours at $42{ }^{\circ} \mathrm{C}$ presented sensibility to physiological potential evaluation of thyme seeds.

The saline solution accelerated aging test using the combination of 24 hours at $38{ }^{\circ} \mathrm{C}$ presented sensibility to physiological potential evaluation of thyme seeds.

For both saline solution and traditional accelerated aging test, the exposition time of 24 hours was efficient to evaluate physiological potential of thyme seeds.

\section{References}

Albuquerque, M. C. F., Moro, F. V., Fagioli, M., \& Ribeiro, M. C. (2001). Electrical conductivity test and potassium leaching in the evaluation of sunflower seeds. Rev. Bras. Sementes, 23, 1-8. https://doi.org/10.17801/0101-3122/rbs.v23n1p1-8

Alves, C. Z., \& Sá, M. E. (2012) Methodology adequation for accelerated aging test in arugula seeds. Semina: Agr. Sci., 33, 2789-2798. http://dx.doi.org/10.5433/1679-0359.2012v33n6Supl1p2789

Bhering, M. C., Dias, D. C. F. S., Vidigal, D. S., \& Naveira, D. S. P. (2006). Accelerated aging of pepper seeds. Rev. Bras. Sementes, 28, 64-71. https://doi.org/10.1590/S0101-31222006000300010

Brasil (2009). Ministry of Agriculture, Livestock and Supply. Secretariat of Agricultural Defense. Rules for seed analysis. Brazilia: MAPA/ACS.

Delouche, J. C., \& Baskin, C. C. (1973). Accelerated aging techniques for predicting the relative storability of seed lots. Seed Sci. Technol., 1, 427-452.

Digest, R. (1999). Secrets and Virtues of Medicinal Plants: A Guide with Hundreds of Native and Exotic Plants and Their Healing Powers. Rio de Janeiro: Reader's Digest. 
Freitas, R. A., \& Nascimento, W. M. (2006). Accelerated aging test on lentil seeds. Rev. Bras. Sementes, 28, 59-63. https://doi.org/10.1590/S0101-31222006000300009

Godoy, A. R., Alves, C. Z., Oliveira, N. C., \& Candido, A. C. S. (2012). Accelerated aging test on the physiological quality of carrot seeds. Visão Academica, 13, 45-54. https://doi.org/10.5380/acd.v13i4.30340

Jianhua, Z., \& McDonald, M. B. (1996). The saturated salt accelerated aging test for small-seeded crops. Seed Sci. Technol., 25, 123-131.

Maguire, J. D. (1962). Speed of germination-aid in selection and evaluation for seedling $\begin{array}{lllll}\text { emergence } \quad \text { and } & \text { vigor. } & \text { Crop } & \text { 176-177. }\end{array}$ https://doi.org/10.2135/cropsci1962.0011183X000200020033x

Marcos Filho, J. (1999). Accelerated aging test. In: Krzyzanowski, F.C., Vieira, R.D., França Neto, J.B. (Ed.) Seed vigor: concepts and tests. Londrina: Abrates. pp. 3.1-3.24.

Marcos Filho, J. (2005). Seed physiology of cultivated plants. Piracicaba: Fealq.

Marcos Filho, J. (2015). Seed vigor and performance. In: Marcos Filho, J. Seed physiology of cultivated plants. 2 ed. Londrina: Abrates. pp.563-613.

Miranda, C. A. S. F., Cardoso, M. G., Carvalho, M. L. M., Machado, S. M. F., Andrade, M. A. A., \& Oliveira, C. M. (2015). Comparative analyses of potential allelopathic of Thymus vulgaris essential oil and its major constituent in germination and vigor of lettuce seeds (Lactuca sativa L.). E-xacta, 8, 45-53. https://doi.org/10.18674/exacta.v8i2.1516

Nakagawa, J. (1999). Stability tests based on seedling performance. In: Krzyzanowski, F.C., Vieira, R.D., França Neto, J.B.F. Seed vigor: concepts and tests. Londrina: Abrates, 2, 1-24.

Ohlson, O. C., Krzyzanowski, F. C., Caieiro, J. T., \& Panobianco, M. (2010). Accelerated ageing test for seed wheat evaluation. Rev. Bras. Sementes, 32, 118-124. https://doi.org/10.1590/S0101-31222010000400013

Panobianco, M., \& Marcos Filho, J. (2001). Accelerated aging and controlled deterioration of tomato seeds. Sci. Agric., 58, 525-531. https://doi.org/10.1590/S0103-90162001000300014

Ramos, N. P., Flor, E. P. D., Mendonça, E. A. F., \& Minami, K. (2004). Accelerated aging of Eruca sativa L. seeds. Rev. Bras. Sementes, 26, 98-103. https://doi.org/10.1590/S0101-31222004000100015

Saito, M. L. (2004). Pesticides: an alternative for pest control in agriculture. Brasília: Embrapa.

Silva, C. B., Pivetta, K. F. L., Oliveira, C. A. V. M., Rodrigues, M. A., \& Vieira, R. D. (2010). Accelerated aging test to evaluate the physiological potential of bermuda grass seeds. Rev. Bras. Sementes, 32, 102-107. https://doi.org/10.1590/S0101-31222010000200012

Tekrony, D. M. (2003). Precision in an essential compriment in seed vigor testing. Seed Sci. Technol., 31, 435-447. https://doi.org/10.15258/sst.2003.31.2.20 


\section{Macrothink}

Journal of Agricultural Studies

ISSN 2166-0379 2021, Vol. 9, No. 1

Torres, S. B. (2005). Accelerated aging of pepper (Capsicum frutescens L.) seeds). Ciênc. Agron., 36, 98-103.

Torres, S. B., \& Marcos Filho, J. (2001). Accelerated aging test on maxixe seeds (Cucumis $\begin{array}{lllll}\text { anguria L.). Rev. Bras. } & \text { Sementes, } & \text { 23, }\end{array}$ https://doi.org/10.17801/0101-3122/rbs.v23n2p108-112

Tunes, L. M., Pedroso, D. C., Badinelli, P. G., Tavares, L. C., Rufino, C. A., Barros, A. C. S. A., \& Muniz, M. F. B. (2011). Accelerated aging of ryegrass seeds submitted to saturated salt solution. Ciênc. Rural, 41, 33-37. https://doi.org/10.1590/S0103-84782011000100006

Tunes, L. M., Tavares, L. C., Rufino, C. R., Barros, A. C. S. A., Muniz, M. F. B., \& Duarte, V. B. (2012). Accelerated aging in broccoli seeds (Brassica oleracea L. var. italica Plenk). Biosci. J., 28, 173-179.

\section{Copyright Disclaimer}

Copyright for this article is retained by the author(s), with first publication rights granted to the journal.

This is an open-access article distributed under the terms and conditions of the Creative Commons Attribution license (http://creativecommons.org/licenses/by/4.0/). 